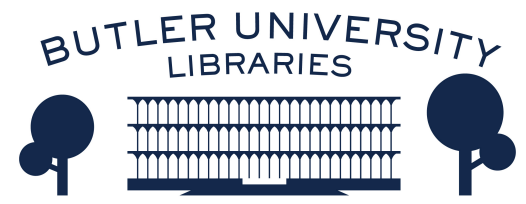

Journal of Hindu-Christian Studies

Volume 32 Discussion of Nathaniel Roberts, To

Be Cared For: The Power of Conversion and

Foreignness of Belonging to An Indian Slum.

Article 20

2019

\title{
Book Review: Privileged Minorities: Syrian Christianity, Gender, and Minority Rights in Postcolonial India
}

Arun W. Jones

Emory University

Follow this and additional works at: https://digitalcommons.butler.edu/jhcs

\section{Recommended Citation}

Jones, Arun W. (2019) "Book Review: Privileged Minorities: Syrian Christianity, Gender, and Minority Rights in Postcolonial India," Journal of Hindu-Christian Studies: Vol. 32, Article 20.

Available at: https://doi.org/10.7825/2164-6279.1746

The Journal of Hindu-Christian Studies is a publication of the Society for Hindu-Christian Studies. The digital version is made available by Digital Commons @ Butler University. For questions about the Journal or the Society, please contact cbauman@butler.edu. For more information about Digital Commons @ Butler University, please contact digitalscholarship@butler.edu. 
imagined Oriental Other; American geography textbooks that added to classificatory systems of race and religion, while promoting the superiority of American culture; and carefully constructed critiques of the typical narratives regarding the roles of Transcendentalism, Thoreau, Emerson, Theosophy, the 1893 World
Parliament of Religions, and much more. There is much to gain from Altman's work, and one hopes it will gain a wide audience.

Jeffrey M. Brackett

Ball State University

\section{Privileged Minorities: Syrian Christianity, Gender, and Minority Rights in Postcolonial India. By Sonja Thomas. Seattle: University of Washington Press, 2018, $\mathrm{x}+210$ pages.}

WHILE there now exist a number of studies of Kerala's Syrian Christians from a variety of different perspectives, Thomas' new investigation provides a fresh and provocative examination of the community using the critical lenses of gender, caste, religion and politics. No doubt, some of the staunch supporters of one of Christianity's oldest traditions will take affront at many of the arguments and claims of the author. However, she has not taken her assignment lightly, providing a rigorous interrogation of the community to which she is personally connected. One may argue and disagree with some of the contentions of the work, as this reviewer does, but one must not dismiss it as unreasonable or unscholarly, and therefore hopelessly biased.

Thomas helpfully locates herself as an insider outsider, growing up in a diasporic Syrian Christian (Syro-Malabar Catholic) community in a rural area of the United States (19). This personal history provides her with a unique scholarly location: as one who speaks the language and understands the culture of her interlocutors, yet as one who has a somewhat different perspective on their community than they generally do. It is, I would argue, this liminal location that provides one of the many fascinating and commendable features of the study, which is that the author critiques a whole range of established scholarship in both South Asian and feminist studies, as she crafts and develops her own arguments and insights into the ways that different segments of the SyroMalabar Catholic community in Travancore, Kerala, have operated to maintain their privilege.

The Introduction of the volume begins by providing a brief demographic and sociological description of the Syrian Christian community in the context of Kerala and of the Indian nation state as a whole. second, it announces the overarching analytical themes that run throughout the work, namely those of gender, caste, class, religion and minority politics. The volume brings together these different vectors of analysis in its examination of Syrian Christians in Kerala (11). Next comes a brief discussion of why scholars have treated Kerala as an exception in their examinations of secularism, and almost completely ignored the issue of education-an issue that the work takes up later. The Introduction ends with an overview of the book's chapters and its research methodology, which employs and engages a number of different academic fields and disciplines. 
Chapter One opens with a historical and sociological description of Kerala. It lays bare the way that high castes dominate, in both the imagination and the reality of the populace, the functioning of Kerala society. These high castes are the Namboodiri Brahmins, the Nayars who were traditionally a martial class, and the Syrian Christians who claim descent from the Namboodiri Brahmins and operate sociologically like the Nayars, engaging in business. There really are no middle castes in Kerala, to speak of; the high castes are separated by a huge social and ritual gulf from the low caste Ezhavas and the slave castes. This caste hierarchy is termed "insane" (22), not the first time in the volume that polemics intrude upon and mar an otherwise scholarly description or argument. The chapter continues by narrating the history and social and religious location of the Syrian Christians in Kerala society, and ends by describing and then interrogating the supposedly exemplary model of Kerala social and economic development.

The next chapter deals with Syrian Christian women's clothing over the course of the twentieth century and into the present. It begins by describing the traditional chatta, thuni and kavani, which were made from white cloth, and which in the middle of the twentieth century were quite rapidly replaced by the sari, which in turn was being replaced by the North Indian churidar or salwar kamize late in the century. There are insightful discussions of how different kinds of clothing (or, in the case of the breast cloth, lack of clothing) both symbolized and operationalized brahminical patriarchal control of women, linking women through their clothing to various castes and classes, and to various social and physical locations (such as the home).
The third chapter discusses race in the (South) Indian context, where fair skin and other physical features denote an "Aryan" origin to Brahmins and other high castes such as Syrian Christians, while dark skin and features such as wooly hair mark others as Dravidian and low or subservient castes. The chapter provides an interesting intervention in South Asian discussions of race, which is often deemed either non-existent (with color being the discriminating feature in South Asian society) or irrelevant. Chapter Four is a historical exploration of some of the political mobilizations in the second half of the twentieth century by Syrian Christians around the issues of dowry prohibition and of education, over which the Syrian churches have considerable control in Kerala. Here Thomas explores the complicated matter of minority rights in India, which are supposed to protect vulnerable populations but have also been used by privileged groups for their vested interests. The final full chapter delves into the topic of marriage, arguing that arranged marriage, religion and caste are intricately interrelated to control social status of various groups, along with individuals' freedoms. The Conclusion discusses future avenues for scholarship of the kind that is generated in the volume.

As noted at the beginning of this review, the work presents new perspectives on the Syrian Christian community in Kerala, through the very productive hermeneutical lenses of feminist critique, caste analysis, class analysis, religion and politics. The chapters are rich with insights and suggestions, some of which may not be completely convincing to all readers, but all of which require serious reflection and engagement. One criticism I have of the work is that at times it is so committed to certain types of perspectives that it distorts or dismisses the evidence at 
hand. For example, the conclusion begins with a report of a sermon at a charismatic retreat where the priest indirectly encourages women to stay in marriages where they are being physically abused by their husbands (147). The impression left is that such sermons are typical in the charismatic movement. Unfortunately, this is just not the case. Such sermons are preached in churches throughout the Christian tradition: Protestant, evangelical, Roman Catholic, Orthodox, charismatic and non-charismatic. Nor are they restricted to ethnic churches such as those composed of diasporic Christians; they are preached in churches across racial and ethnic divides. Speaking more generally, in a justified desire to condemn various abuses of power and authority, the work at times engages in questionable handling of evidence, and also unquestioningly adopts ethical stances that come out of white, Protestant North American society (such as describing caste hierarchy as "insane"). That being said, Privileged Minorities throws new light on significant features of the Syrian Christian community, and hopefully will generate productive conversations and debates in the years to come.

Arun W. Jones

Emory University 